\title{
Influence of breed, milk yield, and temperature-humidity index on dairy cow lying time, neck activity, reticulorumen temperature, and rumination behavior
}

\author{
A. E. Stone, ${ }^{*}$ B. W. Jones,, C. A. Becker, $\nmid$ and J. M. Bewley $\dagger^{1}$ \\ *Department of Animal and Dairy Science, Mississippi State University, Starkville 39759 \\ †Department of Animal and Food Sciences, University of Kentucky, Lexington 40546
}

\begin{abstract}
The objective of this study was to compare weekly mean lying time (LT), neck activity (NA), reticulorumen temperature (RT), and rumination time (RU) among 3 breed groups, milk yield (MY), and temperature-humidity index (THI). Cows $(\mathrm{n}=36 ; 12$ Holstein, 12 crossbred, and 12 Jersey) were blocked by parity group (primiparous or multiparous), days in milk, and MY. Lying time, NA, RT, RU, and MY were recorded and averaged by day and then by week for each cow. For study inclusion, each cow was required to have 10 wk of LT, NA, RT, and RU data. Maximum THI were recorded and averaged daily. Mean $( \pm \mathrm{SE})$ days in milk, LT, MY, RT, RU, NA, and maximum THI were 159.0 $\pm 6.0 \mathrm{~d}, 11.1 \pm 0.1 \mathrm{~h} / \mathrm{d}, 28.7 \pm 0.5 \mathrm{~kg} / \mathrm{d}, 38.8 \pm 0.0^{\circ} \mathrm{C}$, $6.4 \pm 0.1 \mathrm{~h} / \mathrm{d}, 323.8 \pm 3.8$ activity units, and $56.5 \pm$ 0.6 , respectively. The MIXED Procedure of SAS (SAS Institute Inc., Cary, NC) was used to evaluate fixed effects of breed, MY, parity, THI, and their interactions on LT, NA, RT, and RU with cow nested within breed as subject. All main effects remained in each model regardless of significance level. Stepwise backward elimination was used to remove nonsignificant interactions. The interactions of breed $\times$ parity group and maximum THI $\times$ parity group were associated with RT. Increasing THI coincided with increasing RT. Least squares means LT for multiparous cows was significantly greater than LT for primiparous cows $(11.4 \pm 0.3$ and $10.5 \pm 0.5$ $\mathrm{h} / \mathrm{d}$, respectively). Least squares means NA for primiparous cows was greater than for multiparous cows of all breeds (372.1 \pm 10.9 and $303.4 \pm 7.8$, respectively). The CORR Procedure of SAS was used to evaluate relationships among RT, RU, LT, NA, and MY. Rumination time was positively correlated with MY $(\mathrm{r}=$ $0.30)$ and negatively correlated with LT $(\mathrm{r}=-0.14)$. Reticulorumen temperature was negatively correlated with MY $(\mathrm{r}=-0.11)$. Rumination time was positively
\end{abstract}

Received June 13, 2016.

Accepted October 25, 2016.

${ }^{1}$ Corresponding author: jbewley@uky.edu correlated with NA $(\mathrm{r}=0.18)$ and negatively correlated with LT $(\mathrm{r}=-0.14)$. Lying time and NA were negatively correlated $(\mathrm{r}=-0.43)$. Neck activity was positively correlated with MY $(\mathrm{r}=0.14)$. Lying time was negatively correlated with MY $(\mathrm{r}=-0.25)$. Milk yield was associated with RU, which may be related to cows with greater MY also having a greater feed intake. Lying time increased and NA decreased with increasing parity, which may be effects of social hierarchy, where primiparous cows are more susceptible to being pushed away from the feed bunk and freestalls. Milk yield was positively associated with RU. Greater milk production requires greater feed intake, which may result in longer $\mathrm{RU}$ than for low-yielding cows. Lying time decreased as milk yield increased. The behavioral and physiological differences observed in this study provide new insight into the effects that breed, parity, MY, and THI have on cows.

Key words: breed, precision dairy farming

\section{INTRODUCTION}

Precision dairy farming (PDF), or the use of technologies to monitor behavioral, physiological, or production indicators for individual animal disease, estrus, or welfare, is becoming more widely adopted (Svennersten-Sjaunja and Pettersson, 2008; de Koning, 2010) to partly reduce physical labor and labor costs (Rutten et al., 2013). Currently, lying time, rumination time, activity, temperature, and milk yield are a few examples of indicators that can be monitored with PDF technologies.

Many PDF evaluation studies use Holstein cows because they are the predominant dairy breed. However, cows of different breeds may vary in physiological, behavioral, and production responses to various stimuli, which may cause PDF technologies to work differently on cows of different breeds. Cows of different breeds differ in milk yield, milk composition, live weight, body composition (Oldenbroek, 1984), and DMI (Palladino et al., 2010). Crossbreeding may improve dairy cattle health and efficiency through heterosis or the introduc- 
tion of favorable genes from other breeds and removal of inbreeding depression (VanRaden and Sanders, 2003). Crossbreeding can potentially improve calving ease, fertility, health, and survival, which may compensate for the production loss compared with Holsteins (Heins and Hansen 2012).

Although crossbreeding may not be widely adopted in the United States, 20 and 5\% of cows in New Zealand and Australia, respectively, are Jersey and Holstein crosses (VanRaden and Sanders, 2003). Jersey $\times$ Holstein crossbred cows are desired in New Zealand and some other countries, particularly where pasture grazing is common, because of their smaller body size, higher milk fat and protein composition, great ability to calve seasonally, and superior pasture foraging ability (Heins et al., 2011). Weigel and Barlass (2003) explained that crossbreeding has sparked the interest of US producers for 3 reasons: (1) milk pricing changes in some US regions have created rewards for herds with higher fat and protein percentages, (2) concerns exist about female fertility, calving case, health, and survival in Holsteins, and (3) crossbreeding may reduce the consequences of inbreeding depression.

To our knowledge, this is the first study to evaluate differences with PDF technology data among different dairy cattle breeds. The objective of our study was to compare lying time, neck activity, reticulorumen temperature, and rumination behavior among breed groups, milk yield, and temperature-humidity index.

\section{MATERIALS AND METHODS}

This study was conducted at the University of Kentucky Coldstream Dairy from October 8, 2011, to May 15, 2013, under Institutional Animal Care and Use Committee protocol \#2010-0776. Thirty-six lactating cows (12 Holstein, 12 Jersey, 12 crossbred) were matched by parity group (primiparous or multiparous), DIM, and milk yield. General cow demographic information was obtained from PCDart (Dairy Records Management Systems, Raleigh, NC) records. Crossbred cows consisted of Jersey $\times$ Holstein crossbreds $(50 \%$ Holstein, $50 \%$ Jersey, $\mathrm{n}=4$ ), Swedish Red $\times$ Jersey $\times$ Holstein crossbreds (50\% Swedish Red, 25\% Jersey, $25 \%$ Holstein, $\mathrm{n}=7$ ), and a Brown Swiss $\times$ Jersey $\times$ Holstein crossbred (50\% Brown Swiss, 25\% Jersey, 25\% Holstein, $\mathrm{n}=1$ ).

The lactating herd was divided into 2 groups balanced by parity, cow volume (length $\times$ width $\times$ height), stall base type (waterbed or mattress), and DIM for a separate research study. Both groups were housed in freestalls, either sawdust-covered Dual Chamber Cow Waterbeds (Advanced Comfort Technology Inc., Sun Prairie, WI) or sawdust-covered, rubber-filled Pas-
tureMat (Promat, Ontario, Canada) mattresses. Cows shared a feed bunk, accessible from both pens. The lactating herd was fed a TMR of corn silage, alfalfa hay, alfalfa silage, whole cottonseed, and grain mix daily at 0530 and $1330 \mathrm{~h}$. Cows were allowed access to an exercise lot for about $1 \mathrm{~h} / \mathrm{d}$ at $1000 \mathrm{~h}$, weather permitting. Each group was milked $2 \times /$ d, at 0430 and 1530 $\mathrm{h}$, in 1 of 2 double- 2 bypass parlors located in the same building.

The Milpro P4C (Milkline, Gariga di Podenzano, Italy) system provided daily milk weights per cow (milk yield; MY). The DVM Systems LLC (Boulder, $\mathrm{CO})$ bolus system monitored reticulorumen temperature (RT) using a passive radiofrequency identification transponder (Phase IV Engineering Inc., Boulder, CO) equipped with a temperature sensor queried twice daily by a panel reader placed in parlor entrances.

An HR Tag (SCR Engineers Ltd., Netanya, Israel) measured neck activity (NA) with a 3-axis accelerometer and rumination time (RU) with a microphone and microprocessor, summarized into 2-h time blocks. In an HR tag validation study, rumination recordings were highly correlated with live observations $\left(r=0.93, R^{2}=\right.$ 0.87; Schirmann et al., 2009).

An IceQube (IceRobotics Ltd., Edinburgh, UK) device measured lying time (LT) with a 3 -axis accelerometer, summarized into 15-min time blocks. IceTag (IceRobotics) lying and activity monitors were validated and correlations were 0.99 compared with visual observations for lying time (Munksgaard et al., 2006). The monitors used in our study were manufactured by the same company.

All DVM boluses, HR Tags, and IceQubes were assigned to individual cows $\geq 21$ before study enrollment. The DVM bolus was inserted orally using a bolus gun. Each bolus resided in the reticulorumen for the lifetime of the animal. Cows were fitted with an HR tag, snugly hung around their necks with the microphone and microprocessor positioned on the left side. IceQubes were strapped to each cow's left rear leg just above the fetlock.

Hourly temperature and relative humidity were obtained from Kentucky Climate Data, calculated through the University of Kentucky College of Agriculture via a Campbell Scientific Inc. (Logan, UT) $23 \times$ data logger, located $5.63 \mathrm{~km}$ from the farm. Temperature-humidity index (THI) was computed using the following formula (NOAA, 1976): $\mathrm{THI}=$ temperature $\left({ }^{\circ} \mathrm{F}\right)-[0.55-(0.55$ $\times$ relative humidity $/ 100)] \times\left[\right.$ temperature $\left.\left({ }^{\circ} \mathrm{F}\right)-58.8\right]$. The maximum THI for each day was then averaged to obtain the average maximum THI for each week.

Redden et al. (1993) explained that vaginal temperature increased by $0.6 \pm 0.3^{\circ} \mathrm{C}$ at estrus and remained elevated for $6.8 \pm 4.6 \mathrm{~h}$. Restlessness and increased 
activity are also signs of estrus (Van Eerdenburg et al., 1996; Løvendahl and Chagunda, 2010). Because of potential variation from typical cow behavior during estrus, RU, RT, NA, LT, and MY were removed the day before, of, and after an estrus or breeding event. Estrus determination was based on observations from the herd manager or farm staff.

Milk yield data were edited by removing all MY equal to 0 , resulting from milking system misidentification. Milk yield data were also removed if the MY from that day divided by the cow's 7-d backward moving rolling mean baseline was greater than 0.5 , as this was likely the result of system misidentification. Cows were not always cleared from the system before the next cow entered, which was attributed to 2 cows' MY being added together and assigned to the first cow through the parlor. This MY cleaning process was targeted at removing both cows involved in this situation. Bewley et al. (2008a) discovered that when cows ingested cold water, a drastic $9.2 \pm 0.2^{\circ} \mathrm{C}$ RT decrease occurred and $3 \mathrm{~h}$ elapsed before baseline RT was reached. Therefore, raw RT data were edited to remove RT potentially influenced by water intake by removing RT with Zscores $<-3$ from the cow's 7 -d backward rolling mean baseline. Raw RU and NA data were removed when equal to 0 , when the reader did not recognize the cows. Rumination time and NA data were further edited to remove values less than the first percentile or greater than the 99th percentile of the entire data set, determined by the UNIVARIATE procedure of SAS version 9.3 (SAS Institute, Cary, NC). Daily LT of 0 and 24, presumably because of a tag error, were removed from the analysis. Lying time data were further edited to remove values less than the first percentile or greater than the 99th percentile of the entire data set, determined by the UNIVARIATE procedure of SAS. Lastly, LT greater than 3 or less than -3 standard deviations of each cow's group LT average were removed. Rumination time, RT, NA, and MY were only included for DIM between 15 and 400. Cows were required to have 10 periods of 7 consecutive days of recorded RU, RT, $\mathrm{NA}$, and LT to be included in the study. Rumination time, RT, NA, and LT were averaged by day and then by week to obtain 10 wk of data per cow.

The MIXED Procedure of SAS was used to evaluate the fixed effects of breed, MY, parity group, THI, and their interactions on RT, RU, LT, and NA. The subject was cow nested within breed and the covariance structure was autoregressive (1) for all models. All main effects were kept in each model regardless of significance level. Stepwise backward elimination was used to remove nonsignificant interactions $(P \geq 0.05)$. Because cows were housed in 2 barns with different stall bases, barn was evaluated but was not significant in any model so it was not included. Rumination time, RT, NA, LT, and MY were then averaged by cow over the study period and the CORR procedure was used to evaluate relationships among RT, RU, LT, NA, and MY.

\section{RESULTS AND DISCUSSION}

Mean \pm standard error (SE) for parity, DIM, and MY were $2.5 \pm 0.1$ lactations, $159.0 \pm 6 \mathrm{~d}$, and $28.7 \pm$ $0.5 \mathrm{~kg}(\mathrm{n}=352 \mathrm{~d})$. Mean $\pm \mathrm{SE}$ of the THI throughout the study was $56.7 \pm 0.4(\mathrm{n}=351 \mathrm{~d})$. Mean $\mathrm{LT} \pm \mathrm{SE}$ was $11.1 \pm 0.1 \mathrm{~h} / \mathrm{d}(\mathrm{n}=352)$, comparable to results of a study of 43 farms and 2,033 cows, where cows spent $11.0 \mathrm{~h} / \mathrm{d}$ lying down (Ito et al., 2009). Other studies have cited lying times of $10.5 \mathrm{~h} / \mathrm{d}$ (Bewley et al., 2010), $11.9 \mathrm{~h} / \mathrm{d}$ (Gomez and Cook, 2010), and 10.0 to $12.6 \mathrm{~h} / \mathrm{d}$ (Ledgerwood et al., 2010). Mean $\pm \mathrm{SE}$ RT was $38.8^{\circ} \mathrm{C}$ $\pm 0.0(\mathrm{n}=352)$, comparable to the $39.28^{\circ} \mathrm{C} \pm 0.4$ reported in Bewley et al. (2008b). Mean \pm SE NA was $323.8 \pm 3.8(\mathrm{n}=352)$. Mean $\pm \mathrm{SE} \mathrm{RU}$ was $6.4 \pm 0.1$ $\mathrm{h} / \mathrm{d}(\mathrm{n}=352)$, consistent with the 6.3 to $6.5 \mathrm{~h} / \mathrm{d}$ range reported by Moallem et al. (2010). This result was also within the range of 4.8 to $8.4 \mathrm{~h} / \mathrm{d}$ cited by Krause et al. (2002), but less than the 8 to $9 \mathrm{~h} / \mathrm{d}$ recommendation cited by Welch (1982) and the $8.4 \mathrm{~h} / \mathrm{d}$ reported by Soriani et al. (2013). Rumination time differences between studies may be related to ration composition, but these differences are difficult to compare because they are not reported in the publications. The results of the RT, RU, NA, and RT mixed model are displayed in Table 1.

\section{Reticulorumen Temperature}

Mean ( \pm SE) daily RT of Holstein, Jersey, and crossbred cows were $38.9 \pm 0.1,38.7 \pm 0.1$, and 38.8 $\pm 0.1^{\circ} \mathrm{C}$, respectively. This result coincided with the previously cited range of 38.6 to $39.2^{\circ} \mathrm{C}$ with daily variation of 0.8 to $1.8^{\circ} \mathrm{C}$ (Piccione and Refinetti, 2003). However, the mean RT of each breed are less than those cited by Liang et al. (2013; 40.2 $\pm 0.3,40.0 \pm 0.3$, and $40.1 \pm 0.29^{\circ} \mathrm{C}$ for Holstein, Jersey, and crossbred cows, respectively). This difference may be because less frequent temperatures were recorded in the current study compared with the active RT boluses used in Liang et al. (2013). Passive temperature-monitoring systems, such as the one used in our study, typically only record data a few times per day, as animals enter or exit the milking parlor. Active temperature-monitoring systems use battery-operated transponders, which are scheduled to transmit at a set frequency (Small et al., 2008). Frequent temperatures may allow removal of decreased 
Table 1. Type III tests of fixed effects for reticulorumen temperature, rumination time, lying time, and neck activity models including significant interactions and all main effects

\begin{tabular}{|c|c|c|c|c|c|}
\hline Dependent variable & Independent variable $^{1}$ & Numerator df & Denominator df & F-value & $P$-value \\
\hline \multirow{4}{*}{ Reticulorumen temperature $^{2}$} & Parity group & 1 & 30 & 3.70 & 0.06 \\
\hline & Maximum THI & 1 & 312 & 0.26 & 0.61 \\
\hline & Breed $\times$ parity group & 2 & 30 & 9.54 & $<0.01$ \\
\hline & Maximum THI $\times$ parity group & 1 & 312 & 5.28 & 0.02 \\
\hline \multirow[t]{2}{*}{ Rumination time $^{3}$} & Breed & 2 & 32 & 0.61 & 0.55 \\
\hline & Milk yield & 1 & 313 & 14.01 & $<0.01$ \\
\hline \multirow[t]{5}{*}{ Lying time ${ }^{4}$} & Breed & 2 & 32 & 2.98 & 0.07 \\
\hline & Parity group & 1 & 32 & 5.93 & 0.02 \\
\hline & Maximum THI & 1 & 312 & 0.83 & 0.36 \\
\hline & Milk yield & 1 & 312 & 5.21 & 0.02 \\
\hline & Maximum THI $\times$ parity group & 1 & 312 & 3.98 & 0.05 \\
\hline Neck activity ${ }^{5}$ & Breed & 2 & 30 & 3.09 & 0.06 \\
\hline
\end{tabular}

${ }^{1}$ Breed $=$ Holstein, Jersey, or crossbred; parity group = primiparous or multiparous; maximum THI $=$ maximum daily temperature-humidity index obtained through the University of Kentucky College of Agriculture via a data logger located $5.63 \mathrm{~km}$ from the farm; milk yield = Milpro P4C (Milkline, Gariga di Podenzano, Italy) provided daily milk weights (kg/cow).

${ }^{2}$ Reticulorumen temperature mixed model using a passive radiofrequency identification transponder equipped with a temperature sensor queried twice daily by a panel reader placed in parlor entrances.

${ }^{3}$ HR Tag (SCR Engineers Ltd., Netanya, Israel) measured rumination time with a microphone and microprocessor.

${ }^{4}$ IceQubes (IceRobotics Ltd., Edinburgh, Scotland, UK) measured lying time with a 3-axis accelerometer, summarized into 15-min time blocks. ${ }^{5} \mathrm{HR}$ Tag (SCR Engineers Ltd.) measured neck activity with a 3-axis accelerometer.

temperatures resulting from water intake while still allowing enough temperatures for analysis (Bewley et al., 2008a).

Breed $\times$ parity group and maximum THI $\times$ parity group were associated with RT $(P<0.01$ and $P=0.02$, respectively). Least squares means from the RT mixed model are displayed in Table 2. Kendall and Webster (2009) did not observe a significant vaginal temperature difference among Holstein, Jersey, and Holstein $x$ Jersey crossbred cows other than a tendency for Jersey cows to maintain a greater temperature in the summer compared with Holstein and Holstein $\times$ Jersey crossbred cows. Results from Liang et al. (2013) and Smith et al. (2013) implied that a Jersey cow's ability to maintain a lower RT may provide some advantage over Holstein and crossbred cows under conditions of heat stress. This result was comparable to the primiparous breed differences in RT in our study, where primiparous Holstein cows had greater RT than Jersey crossbred cows and crossbred cows had greater RT than Jersey cows. Physiological responses to ambient conditions are breed-specific because of body size, skin color, sweating rate, respiration rate, and heat production (Finch, 1986; Kadzere et al., 2002). Increased milk production can also elevate body temperature (Igono et al., 1985). High-producing cows $(31.6 \mathrm{~kg} / \mathrm{d})$ produce $48.5 \%$ more body heat than dry cows (Purwantoa et al., 1990) because body heat increases as metabolic processes, feed intake, and digestive requirements increase, which occurs as milk yield increases (West, 2003). However, significant RT differences between breeds were not evident in multiparous cows.

Understanding breed differences for heat tolerance could allow dairy producers in hot climates to select cattle most suitable to their area to prevent production losses caused by heat stress (Smith et al., 2013). Understanding differences within different breeds could also allow producers the potential to select for more heattolerant cows within each breed. However, in our study,

Table 2. Least squares means $( \pm \mathrm{SE})$ reticulorumen temperature $\left({ }^{\circ} \mathrm{C}\right)$ within the parity group $\times$ breed interaction, using a passive radiofrequency identification transponder equipped with a temperature sensor queried twice daily by a panel reader placed in parlor entrances

\begin{tabular}{lll}
\hline & \multicolumn{2}{c}{ Parity group } \\
\cline { 2 - 3 } Breed & Primiparous & Multiparous \\
\hline Holstein & $39.3 \pm 0.2^{\mathrm{a}}$ & $38.4 \pm 0.2^{\mathrm{cd}}$ \\
Jersey & $38.2 \pm 0.2^{\mathrm{d}}$ & $39.1 \pm 0.2^{\mathrm{bc}}$ \\
Crossbred & $38.9 \pm 0.2^{\mathrm{b}}$ & $38.8 \pm 0.2^{\mathrm{bcd}}$ \\
\hline
\end{tabular}

$\overline{\mathrm{a}-\mathrm{d}}$ Least squares means with different superscripts within rows and columns differ $(P<0.05)$. 
the differences only lasted for the first lactation and, thus, may accurately represent the breed as a whole.

\section{Rumination Time}

Milk yield was positively associated with RU $(P<$ 0.01; Figure 1). Fregonesi and Leaver (2002) explained that greater feed intakes of high-yielding cows resulted in longer RU than for low-yielding cows. Dairy personnel usually associate a positive relationship between daily feed intake and RU because greater intakes may require more ruminal processing time (Schirmann et al., 2012). Krause et al. (2002) explained that a positive relationship between long particle DMI and rumination time also exists. However, Canadian researchers discovered a negative relationship between RU and DMI in dry cows $(\mathrm{r}=-0.18 ; P<0.01)$, possibly because cows cannot eat and ruminate at the same time (Schirmann et al., 2012).

Before the invention of automated rumination-logging systems, researchers estimated rumination time based on direct visual observations. In an early study evaluating physiological breed differences with only 2 cows, rumination time per gram of cell wall constituent intake was higher for the Jersey than for the Holstein after correcting for BW (Welch et al., 1970). Automated rumination-monitoring systems can provide a reasonable measure of rumination in lactating dairy cows.

\section{Lying Time}

Lying is a high priority behavior in dairy cattle (Munksgaard et al., 2005). Social ranking (Galindo and Broom, 2000), production (Fregonesi and Leaver, 2001), lameness (Walker et al., 2008), and illness or pain (Cyples et al., 2012) may influence individual cow lying times. Electronic data loggers that measure lying behavior can be used in behavioral studies to evaluate lying time differences (Gomez and Cook, 2010).

Lying time decreased as milk yield increased (Figure 2 ). Cows with greater MY have higher nutrient requirements and may spend more time consuming feed rather than lying down (Fregonesi and Leaver, 2002). Finnish researchers explained that, although cows with greater MY spent less time lying and more time ruminating while standing, MY did not significantly affect total RU (Norring et al., 2012).

The relationship between LT and the interaction of maximum THI $\times$ parity group is displayed in Figure 3. Least squares means LT for multiparous cows was significantly greater than that of primiparous cows $(11.4 \pm 0.3$ and $10.5 \pm 0.5 \mathrm{~h} / \mathrm{d}$, respectively; $P=0.02)$. This result is in agreement with previous research that showed daily LT increased with increasing parity (Norring et al., 2008), possibly in part from multiparous cows ruminating for a longer time while lying compared with primiparous cows. Primiparous cows also relaxed

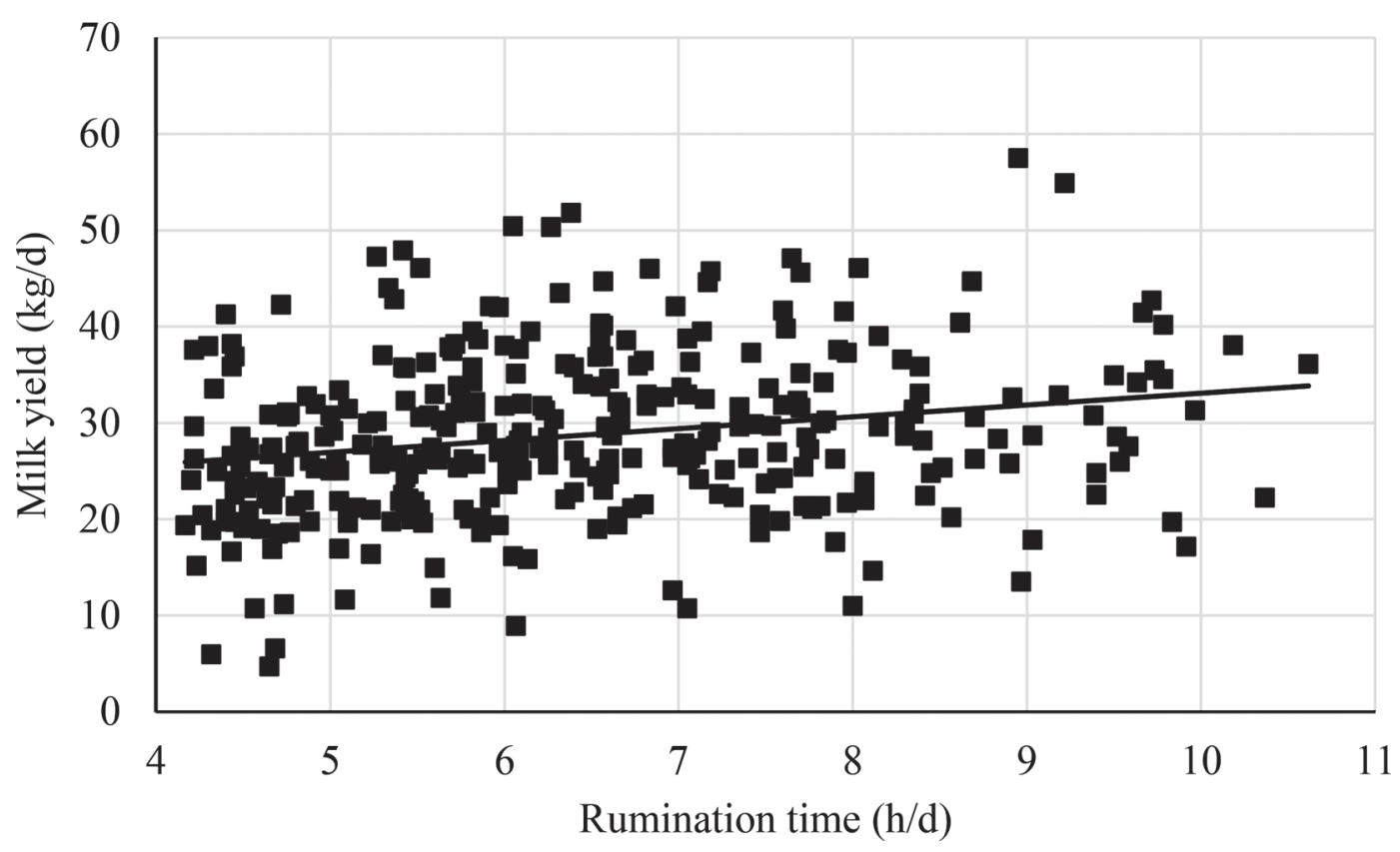

Figure 1. Rumination time in relation to milk yield. All 36 cows had 10 wk of rumination time and milk yield, each of which were averaged per day and then per week. Rumination time was associated with milk yield $(P<0.01)$. The Milpro P4C (Milkline, Gariga di Podenzano, Italy) provided daily milk weights per cow. An HR Tag (SCR Engineers Ltd., Netanya, Israel) measured rumination time with a microphone and microprocessor. Cows included 12 Holstein, 12 crossbred, and 12 Jersey. The $\mathrm{R}^{2}$ value was 0.05 for this model. 


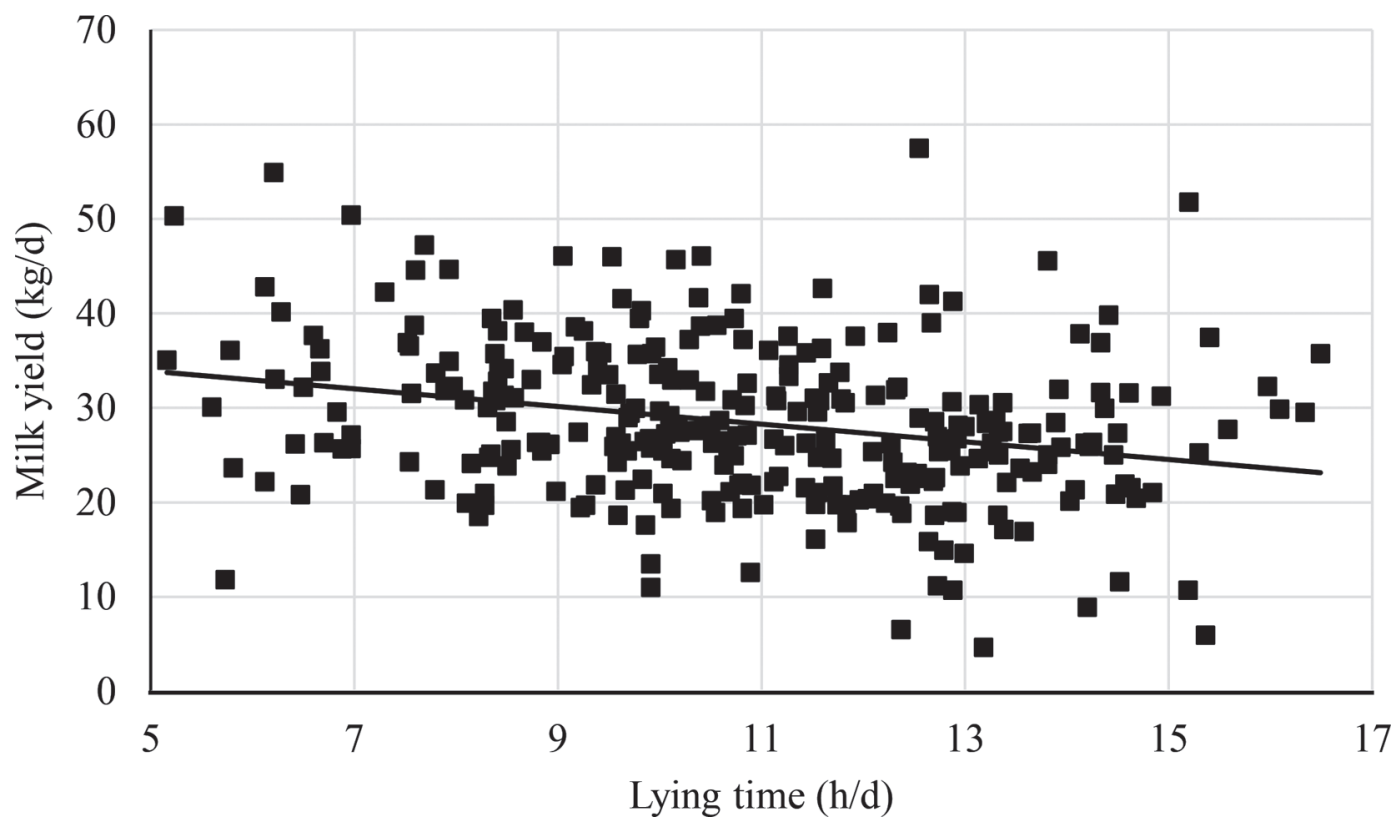

Figure 2. Lying time in relation to milk yield. All 36 cows had 10 wk of lying time and milk yield, each of which were averaged per day and then per week. Lying time was associated with milk yield $(P=0.02)$. The Milpro P4C (Milkline, Gariga di Podenzano, Italy) provided daily milk weights per cow. IceQubes (IceRobotics Ltd., Edinburgh, UK) measured lying time with a 3-axis accelerometer, summarized into 15-min time blocks. Cows included 12 Holstein, 12 crossbred, and 12 Jersey. The $\mathrm{R}^{2}$ value was 0.07 for this model.

their necks without ruminating sooner after lying down than did multiparous cows, implying they fell asleep faster (Norring et al., 2012). This may be a result of heifers being more motivated to sleep than multiparous cows because they are still growing (Hänninen et al., 2003).

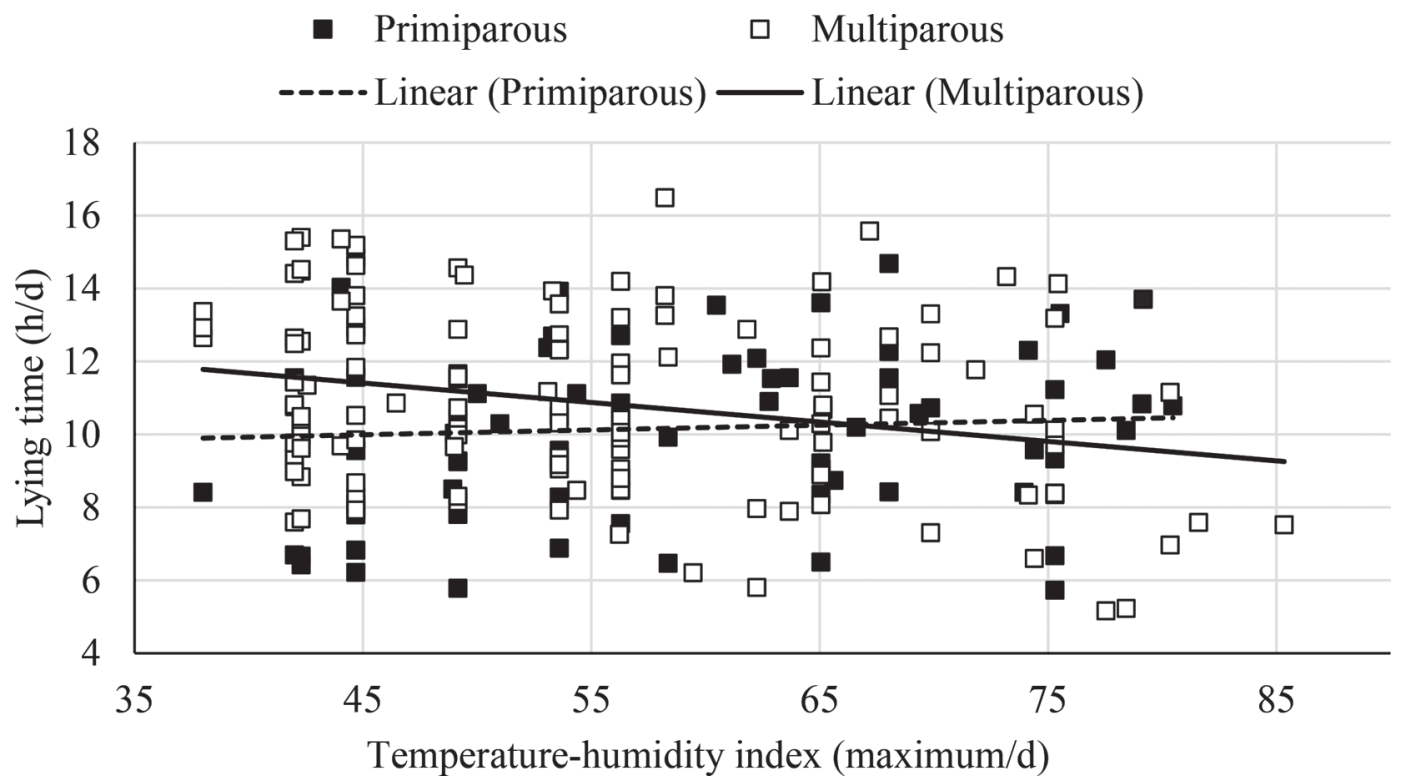

Figure 3. The interaction of temperature-humidity index by parity group (primiparous and multiparous) in relation to lying time. All 36 cows had 10 wk of lying time and temperature-humidity index, each of which were averaged per day and then per week. Temperature-humidity index $\times$ parity group was associated with lying time $(P=0.05)$. Maximum temperature-humidity index for each day was averaged to obtain the average maximum for each week. IceQubes (IceRobotics Ltd., Edinburgh, UK) measured lying time with a 3-axis accelerometer. Cows included 12 Holstein, 12 crossbred, and 12 Jersey. The $\mathrm{R}^{2}$ value was 0.01 for this model. 


\section{Neck Activity}

Neck activity ranged from 112.1 to 506.6 activity units/d. Least squares means NA for the interaction of breed $\times$ parity group are displayed in Table 3 . Proudfoot et al. (2009) explained that primiparous cows competing for a spot at the feed bunk (2:1 cows:feed bin ratio) were displaced more than cows that had individual feed bins. In general, cows of low social rank are displaced more frequently while eating. Subordinate cows have been observed standing and lying to a greater extent around milkings (Olofsson, 1999). Because primiparous cows may have been displaced from the feed bunk more often, they may have had to walk from the feed bunk to the freestalls more often than their dominant counterparts, and thus their activity may have been greater than multiparous cows.

\section{Correlations}

Correlations between MY, LT, RU, NA, and RT are listed in Table 4. Milk yield was positively correlated with RU and NA and negatively correlated with LT. These results are likely because greater-yielding cows need to eat more, causing them to lie down less and ruminate more. Neck activity would likely increase as cows visited the feedbunk more often also. Reticulorumen temperature was negatively correlated with MY, consistent with results from Bewley et al. (2008b) in which RT also decreased with increasing MY.

Rumination time was negatively correlated with LT, contrary to the results of Schirmann et al. (2012), who explained that cows ruminate more when lying down. This result may be an effect of the older and poorly designed freestalls present in the barns, where cows felt more comfortable ruminating while standing. Additionally, RU was positively correlated with NA; this result was probably related to cows ruminating more while standing as opposed to lying down. Lying time and NA were negatively correlated because a cow cannot realistically lie down and be active at the same time. The amount of variation accounted for within these models was limited, however.

\section{Limitations}

Mean $( \pm \mathrm{SE}) \mathrm{MY}$ was $30.9 \pm 0.5,24.3 \pm 0.3$, and 28.4 $\pm 0.4 \mathrm{~kg} / \mathrm{d}$ for Holstein, Jersey, and crossbred cows, respectively. Milk yield naturally varies based on breed and parity, and including these 3 variables together may have created confounding effects. However, these variables could have had had different effects on the parameters being evaluated, so they were included in
Table 3. Least squares means $( \pm \mathrm{SE})$ neck activity within parity group and breed using a neck-based activity monitor ${ }^{1}$

\begin{tabular}{lcc}
\hline \multirow{2}{*}{ Breed } & \multicolumn{2}{c}{ Parity group } \\
\cline { 2 - 3 } & Primiparous & Multiparous \\
\hline Holstein & $365.0 \pm 18.9^{\mathrm{a}}$ & $262.8 \pm 19.4^{\mathrm{c}}$ \\
Jersey & $396.3 \pm 18.6^{\mathrm{a}}$ & $306.7 \pm 13.4^{\mathrm{c}}$ \\
Crossbred & $357.0 \pm 18.6^{\mathrm{ab}}$ & $341.2 \pm 13.7^{\mathrm{b}}$ \\
\hline
\end{tabular}

${ }^{\mathrm{a}-\mathrm{C}}$ Least squares means with different superscripts within rows and columns differ $(P<0.05)$.

${ }^{1}$ HR Tag (SCR Engineers Ltd., Netanya, Israel) measured neck activity with a 3 -axis accelerometer.

the models. Results from higher- or lower-yielding cows than those in our study may differ.

Although an equal number of crossbreds, Holsteins, and Jersey cows were included in our study, the genetic composition of the crossbreds varied between 3 different groupings. Therefore, some differences or lack of differences may have been because not all crossbred cows were the same breed composition, which may have affected measurements within the crossbred group.

\section{CONCLUSIONS}

Milk yield was associated with RU, which may be related to cows with greater MY also having a greater feed intake. Lying time increased and NA decreased with increasing parity, which may be effects of social hierarchy, where primiparous cows are more susceptible to being pushed away from the feed bunk and freestalls. Milk yield was positively associated with RU. Greater

Table 4. Correlations between 4 variables monitored using precision dairy farming technologies on 36 cows (12 Holstein, 12 Jersey, and 12 crossbred cows) over $10 \mathrm{wk}^{1}$

\begin{tabular}{lrr}
\hline Variable & \multicolumn{1}{c}{$\mathrm{r}$} & $P$-value \\
\hline Rumination time, lying time & -0.14 & 0.01 \\
Rumination time, milk yield & 0.30 & $<0.01$ \\
Rumination time, neck activity & 0.18 & $<0.01$ \\
Rumination time, lying time & -0.14 & 0.01 \\
Reticulorumen temperature, lying time & 0.10 & 0.06 \\
Reticulorumen temperature, neck activity & -0.003 & 0.96 \\
Reticulorumen temperature, milk yield & -0.11 & 0.05 \\
Lying time, neck activity & -0.43 & $<0.01$ \\
Lying time, milk yield & -0.25 & $<0.01$ \\
Neck activity, milk yield & 0.14 & 0.01 \\
\hline
\end{tabular}

${ }^{1}$ The Milpro P4C (Milkline, Gariga di Podenzano, Italy) system provided daily milk weights per cow; a DVM Systems LLC (Boulder, $\mathrm{CO})$ bolus system monitored reticulorumen temperature using a passive radiofrequency identification transponder (Phase IV Engineering Inc., Boulder, CO) equipped with a temperature sensor queried twice daily by a panel reader placed in parlor entrances; an HR Tag (SCR Engineers Ltd., Netanya, Israel) measured neck activity with a 3 -axis accelerometer and rumination time with a microphone and microprocessor. 
milk production requires greater feed intake, which may result in longer RU than for low-yielding cows. Lying time decreased as milk yield increased. The behavioral and physiological differences observed in this study provide new insight into the effects that breed, parity, MY, and THI have on cows. These results could be useful for interpreting technology data.

\section{ACKNOWLEDGMENTS}

The authors extend their sincere thanks to the American Jersey Cattle Association (Reynoldsburg, $\mathrm{OH}$ ) for the funding to complete this project. The authors are grateful to DVM Systems (Boulder, CO), IceRobotics (Edinburgh, UK), Micro Dairy Logic (Amarillo, TX), Milkline (Gariga di Podenzano, Italy), and SCR Engineers (Netanya, Israel) for their technology donations. We appreciate the late Bill Silvia, Glen Aiken, and Kristen McQuerry (University of Kentucky) for their insight on the statistical analysis. We also thank Jack McAllister (University of Kentucky) for creating the crossbreeding program at the university farm. Last, the authors thank Alan Fahey (University College Dublin, Belfield, Ireland) for statistical help.

\section{REFERENCES}

Bewley, J. M., M. Grott, M. Einstein, and M. Schutz. 2008a. Impact of intake water temperatures on reticular temperatures of lactating dairy cows. J. Dairy Sci. 91:3880-3887.

Bewley, J. M., R. E. Boyce, J. Hockin, L. Munksgaard, S. D. Eicher, M. E. Einstein, and M. M. Schutz. 2010. Influence of milk yield, stage of lactation, and body condition on dairy cattle lying behaviour measured using an automated activity monitoring sensor. J. Dairy Res. 77:1-6.

Bewley, J. M., M. E. Einstein, M. W. Grott, and M. M. Schutz. 2008b. Comparison of reticular and rectal core body temperatures in lactating dairy cows. J. Dairy Sci. 91:4661-4672.

Cyples, J. A., C. E. Fitzpatrick, K. E. Leslie, T. J. DeVries, D. B. Haley, and N. Chapinal. 2012. Short communication: The effects of experimentally induced Escherichia coli clinical mastitis on lying behavior of dairy cows. J. Dairy Sci. 95:2571-2575.

de Koning, C. J. A. M. 2010. Automatic Milking-Common Practice on Dairy Farms. Pages 52-67 in Proc. First North Am. Conf. Precision Dairy Management, Toronto, Canada. Elsevier Science B. V., Amsterdam, the Netherlands.

Finch, V. A. 1986. Body temperature in beef cattle: its control and relevance to production in the tropics. J. Anim. Sci. 62:531-542.

Fregonesi, J. A., and J. D. Leaver. 2001. Behaviour, performance and health indicators of welfare for dairy cows housed in strawyard or cubicle systems. Livest. Prod. Sci. 68:205-216.

Fregonesi, J. A., and J. D. Leaver. 2002. Influence of space allowance and milk yield level on behaviour, performance and health of dairy cows housed in strawyard and cubicle systems. Livest. Prod. Sci. $78: 245-257$.

Galindo, F., and D. Broom. 2000. The relationships between social behaviour of dairy cows and the occurrence of lameness in three herds. Res. Vet. Sci. 69:75-79.

Gomez, A., and N. Cook. 2010. Time budgets of lactating dairy cattle in commercial freestall herds. J. Dairy Sci. 93:5772-5781.

Hänninen, L., H. Hepola, J. Rushen, A. M. de Passillé, P. Pursiainen, V. m. Tuure, L. Syrjälä-qvist, M. Pyykkönen, and H. Saloniemi.
2003. Resting behaviour, growth and diarrhoea incidence rate of young dairy calves housed individually or in groups in warm or cold buildings. Acta Agric. Scand. A Anim. Sci. 53:21-28.

Heins, B. J., and L. B. Hansen. 2012. Short communication: Fertility, somatic cell score, and production of Normande $\times$ Holstein, Montbéliarde $\times$ Holstein, and Scandinavian Red $\times$ Holstein crossbreds versus pure Holsteins during their first 5 lactations. J. Dairy Sci. 95:918-924.

Heins, B. J., L. B. Hansen, A. J. Seykora, A. R. Hazel, D. G. Johnson, and J. G. Linn. 2011. Short communication: Jersey $\times$ Holstein crossbreds compared with pure Holsteins for production, mastitis, and body measurements during the first 3 lactations. J. Dairy Sci 94:501-506

Igono, M. O., B. J. Steevens, M. D. Shanklin, and H. D. Johnson 1985. Spray cooling effects on milk production, milk, and rectal temperatures of cows during a moderate temperate summer season. J. Dairy Sci. 68:979-985.

Ito, K., D. Weary, and M. von Keyserlingk. 2009. Lying behavior Assessing within-and between-herd variation in free-stall-housed dairy cows. J. Dairy Sci. 92:4412-4420.

Kadzere, C. T., M. R. Murphy, N. Silanikove, and E. Maltz. 2002 Heat stress in lactating dairy cows: A review. Livest. Prod. Sci. 77:59-91.

Kendall, P. E., and J. R. Webster. 2009. Season and physiological status affects the circadian body temperature rhythm of dairy cows. Livest. Sci. 125:155-160.

Krause, K. M., D. K. Combs, and K. A. Beauchemin. 2002. Effects of forage particle size and grain fermentability in midlactation cows. II. Ruminal pH and chewing activity. J. Dairy Sci. 85:1947-1957.

Ledgerwood, D. N., C. Winckler, and C. Tucker. 2010. Evaluation of data loggers, sampling intervals, and editing techniques for measuring the lying behavior of dairy cattle. J. Dairy Sci. 93:5129-5139.

Liang, D., C. L. Wood, K. J. McQuerry, D. L. Ray, J. D. Clark, and J M. Bewley. 2013. Influence of breed, milk production, season, and ambient temperature on dairy cow reticulorumen temperature. J. Dairy Sci. 96:5072-5081.

Løvendahl, P., and M. G. G. Chagunda. 2010. On the use of physical activity monitoring for estrus detection in dairy cows. J. Dairy Sci. 93:249-259.

Moallem, U., G. Altmark, H. Lehrer, and A. Arieli. 2010. Performance of high-yielding dairy cows supplemented with fat or concentrate under hot and humid climates. J. Dairy Sci. 93:3192-3202.

Munksgaard, L., M. B. Jensen, L. J. Pedersen, S. W. Hansen, and L. Matthews. 2005. Quantifying behavioural priorities - effects of time constraints on behaviour of dairy cows, Bos taurus. Appl. Anim. Behav. Sci. 92:3-14.

Munksgaard, L., C. G. Reenen, and R. Boyce. 2006. Automatic monitoring of lying, standing, and walking behavior in dairy cattle. Page 304 in Proc. Joint Annual Meeting, Minneapolis, MN. Elsevier Science B. V., Amsterdam, the Netherlands.

NOAA. 1976. Livestock hot weather stress. U. S. D. Commerce, N. W. S. C. Reg, and R. O. M. L. C-31-76, ed. U.S. Govt. Printing Office, Washington, DC

Norring, M., E. Manninen, A. De Passillé, J. Rushen, L. Munksgaard, and H. Saloniemi. 2008. Effects of sand and straw bedding on the lying behavior, cleanliness, and hoof and hock injuries of dairy cows. J. Dairy Sci. 91:570-576.

Norring, M., A. Valros, and L. Munksgaard. 2012. Milk yield affects time budget of dairy cows in tie-stalls. J. Dairy Sci. 95:102-108.

Oldenbroek, J. 1984. A comparison of Holstein Friesians, Dutch Friesians and Dutch Red and Whites. I. Production characteristics. Livest. Prod. Sci. 11:69-81.

Olofsson, J. 1999. Competition for total mixed diets fed for ad libitum intake using one or four cows per feeding station. J. Dairy Sci. 82:69-79.

Palladino, R. A., F. Buckley, R. Prendiville, J. J. Murphy, J. Callan, and D. A. Kenny. 2010. A comparison between Holstein-Friesian and Jersey dairy cows and their F1 hybrid on milk fatty acid composition under grazing conditions. J. Dairy Sci. 93:2176-2184.

Piccione, G., and R. Refinetti. 2003. Thermal chronobiology of domestic animals. Front. Biosci. 8:258-264. 
Proudfoot, K. L., D. M. Veira, D. M. Weary, and M. A. G. von Keyserlingk. 2009. Competition at the feed bunk changes the feeding, standing, and social behavior of transition dairy cows. J. Dairy Sci. 92:3116-3123.

Purwantoa, B. P., Y. Aboa, R. Sakamotoa, F. Furumotoa, and S. Yamamoto. 1990. Diurnal patterns of heat production and heart rate under thermoneutral conditions in Holstein Friesian cows differing in milk production. J. Agric. Sci. 114:139-142.

Redden, K. D., A. D. Kennedy, J. R. Ingalls, and T. L. Gilson. 1993 Detection of estrus by radiotelemetric monitoring of vaginal and ear skin temperature and pedometer measurements of activity. J. Dairy Sci. 76:713-721.

Rutten, C. J., A. G. J. Velthuis, W. Steeneveld, and H. Hogeveen 2013. Invited review: Sensors to support health management on dairy farms. J. Dairy Sci. 96:1928-1952.

Schirmann, K., N. Chapinal, D. Weary, W. Heuwieser, and M. von Keyserlingk. 2012. Rumination and its relationship to feeding and lying behavior in Holstein dairy cows. J. Dairy Sci. 95:3212-3217.

Schirmann, K., M. A. von Keyserlingk, D. Weary, D. Veira, and W. Heuwieser. 2009. Technical note: Validation of a system for monitoring rumination in dairy cows. J. Dairy Sci. 92:6052-6055.

Small, J., A. Kennedy, and S. Kahane. 2008. Core body temperature monitoring with passive transponder boluses in beef heifers. Can. J. Anim. Sci. 88:225-235.

Smith, D. L., T. Smith, B. J. Rude, and S. H. Ward. 2013. Short communication: Comparison of the effects of heat stress on milk and component yields and somatic cell score in Holstein and Jersey cows. J. Dairy Sci. 96:3028-3033.

Soriani, N., G. Panella, and L. Calamari. 2013. Rumination time during the summer season and its relationships with metabolic conditions and milk production. J. Dairy Sci. 96:5082-5094.

Svennersten-Sjaunja, K. M., and G. Pettersson. 2008. Pros and cons of automatic milking in Europe. J. Anim. Sci. 86:37-46.

Van Eerdenburg, F. J. C. M., H. S. H. Loeffler, and J. H. van Vliet. 1996. Detection of oestrus in dairy cows: A new approach to an old problem. Vet. Q. 18:52-54.

VanRaden, P. M., and A. Sanders. 2003. Economic merit of crossbred and purebred US dairy cattle. J. Dairy Sci. 86:1036-1044.

Walker, S. L., R. Smith, J. Routly, D. Jones, M. Morris, and H. Dobson. 2008. Lameness, activity time-budgets, and estrus expression in dairy cattle. J. Dairy Sci. 91:4552-4559.

Weigel, K. A., and K. A. Barlass. 2003. Results of a producer survey regarding crossbreeding on US dairy farms. J. Dairy Sci. 86:41484154.

Welch, J. 1982. Rumination, particle size and passage from the rumen. J. Anim. Sci. 54:885-894.

Welch, J. G., A. M. Smith, and K. S. Gibson. 1970. Rumination time in four breeds of dairy cattle. J. Dairy Sci. 53:89-91.

West, J. W. 2003. Effects of heat-stress on production in dairy cattle. J. Dairy Sci. 86:2131-2144. 